\title{
HUBUNGAN KONDISI RUMAH DENGAN KEJADIAN ISPA DI DESA KOTAGAJAH KECAMATAN KOTAGAJAH KABUPATEN LAMPUNG TENGAH
}

\author{
Rizky Anindya Putri ${ }^{1)}$
}

\begin{abstract}
Abstrak
Infeksi Saluran Pernafasan Akut (ISPA) adalah penyakit terbanyak yang dilaporkan. Secaar global, World Health Organization (WHO) memperkirakan setiap tahunnya sekitar 13 juta anak balita meninggal karena ISPA, dan mayoritas terjadi di negara-negara berkembang. Berdasarkan data Dinas Kesehatan Provinsi Lampung tahun 2014, ISPA menempati sepuluh besar penyakit di Provinsi Lampung dengan jumlah kasus sebanyak 259.811 (15,0\%). Berdasarkan profil Puskesmas Rawat Inap Kotagajah tahun 2014-2015, ISPA masih menjadi penyakit dominan berbasis lingkungan di puskesmas tersebut.

Metode yang dilakukan dalam Penelitian ini adalah dengan menggunakan pendekatan potong lintang (cross sectional). Teknik sampling yang digunakan dalam penelitian ini adalah sample secara acak (sample random).

Hasil hasil uji statistik yang telah dilakukan, dapat disimpulkan dari 205 responden sebanyak 89 responden $(43,3 \%)$ menderita ispa, terdapat hubungan antara kepadatan hunian kamar responden, ventilasi alamiah, suhu, kelembaban, kondisi lantai, kondisi dinding, dan tidak terdapat hubungan antara lubang asap dapur.
\end{abstract}

Kata Kunci: ISPA, Kondisi Rumah

${ }^{1)}$ Alumni Prodi D4 Kesehatan Lingkungan Poltekkes Tanjungkarang

\section{PENDAHULUAN}

Infeksi Saluran Pernafasan Akut (ISPA) adalah penyakit terbanyak yang dilaporkan kepada pelayanan kesehatan. World Health Organization (WHO) memperkirakan insidensi ISPA di negara berkembang dengan angka kematian pada anak balita sekitar 40 per 1000 kelahiran hidup, atau $15 \%-20 \%$ pertahun. Setiap tahunnya, ISPA menjadi penyebab utama kematian pada 4 juta anak balita dari total sekitar 13 juta kematian anak balita di seluruh dunia (WHO, 2007).

ISPA dipengruhi oleh beberapa faktor yaitu faktor ekstrinsik dan intrinsik. Faktor ekstrinsik antara lain dari kepadatan hunian, ventilasi, pencahayaan, kadar debu dalam rumah, lubang asap dapur dan konstruksi bangunan. Sedangkan faktor intrinsik terdiri dari umur, jenis kelamin, dan status gizi. Berdasarkan hasil penelitian Aristi, dkk (2014), diperoleh hubungan yang bermakna antara kondisi rumah dengan kejadian ISPA. Kondisi rumah yang tidak sehat memberikan risiko 1,67 kali lebih besar terhadap kejadian ISPA (OR=1,677; $95 \% \mathrm{CI}=1,186-2,327$ ). Hasil penelitian Bee, dkk
(2014) menyimpulkan adanya hubungan yang bermakna antara ISPA dengan ventilasi $(\mathrm{p}<0,05)$ dan lantai rumah $(\mathrm{p}<0,05)$.

Menurut WHO rumah adalah suatu struktur fisik yang dipakai manusia untuk tempat berlindung, dimana lingkungan dari struktur tersebut termasuk juga fasilitas dan pelayanan yang diperlukan, perlengkapan yang berguna untuk kesehatan jasmani dan rohani serta keadaan sosial yang baik untuk keluarga dan individu. Untuk mewujudkan rumah dengan fungsi diatas, rumah tidak harus mewah/besar tetapi rumah yang sederhanapun dapat dibentuk menjadi rumah yang layak huni. Menurut Depkes RI (2007), rumah sehat adalah sarana atau tempat berlindung dan bernaung serta tempat untuk beristirahat sehingga menumbuhkan kehidupan yang sempurna baik fisik, rohani maupun sosial budaya.

Dalam buku pedoman pengendalian ISPA tahun 2012, kasus terbanyak ISPA terjadi di India (43 juta), Cina (21 juta), Pakistan (10 juta), dan Bangladesh, Indonesia, Nigeria masing-masing 6 juta episode. Dari semua kasus yang terjadi di masyarakat, 7-3\% kasus 
berat dan memerlukan perawatan rumah sakit. Episode batuk pilek pada balita di Indonesia diperkirakan 2-3 kali per tahun (Rudan et al Bulletin WHO 2008), ISPA merupakan salah satu penyebab utama kunjungan pasien di Puskesmas (40\%-60\%) dan rumah sakit (15\%$30 \%)$.

Berdasarkan data Dinas Kesehatan Provinsi Lampung tahun 2014, ISPA merupakan penyakit saluran atas yang banyak diderita oleh masyarakat di Provinsi Lampung. ISPA selalu menempati sepuluh besar penyakit di Provinsi Lampung dengan jumlah kasus sebanyak $259.811(15,00 \%)$.

Hasil studi pendahuluan yang dilakukan di Desa Kotagajah Kabupaten Lampung Tengah mendapatkan, bahwa dari 10 rumah yang diobservasi, sebanyak lima belum memenuhi syarat rumah sehat. Data kunjungan masyarakat yang tercatat pada Puskesmas Rawat Inap Kotagajah selama dua tahun terakhir (20142016), tertinggi dengan keluhan ISPA terdapat 938 kasus dengan kasus tertinggi terdapat di Desa Kotagajah, sebanyak 465 kasus. Penelitian bertujuan mengetahui hubungan kondisi rumah dengan kejadian ISPA di Desa Kotagajah Kecamatan Kotagajah, Kabupaten Lampung Tengah.

\section{METODE}

Penelitian yang dilakukan dengan mengguunakan rancangan potong lintang (cross sectional). Desain yang efisien untuk mendeskripsikan distribusi penyakit dihubungkan dengan distribusi sejumlah karakteristik populasi. Variabel penelitian adalah kejadian ISPA, kepadatan hunian kamar, ventilasi alamiah, suhu, kelembaban, lantai rumah, dinding rumah, dan lubang asap dapur.

Penelitian dilakukan di Desa Kotagajah Kecamatan Kotagajah Kabupaten Lampung Tengah Provinsi Lampung pada bulan MeiJuni 2017. Populasi penelitian adalah seluruh rumah tangga sebanyak 415 rumah tangga. Sampel sebanyak 205 rumah tangga, dihitung berdasarkan estimasi proporsi mengikuti Notoadmojo (2007). Pemilihan sampel dengan systematic random sampling. Kriteria sampel adalah berdomisili tetap di lokasi penelitian, menempati rumah secara menetap minimal dalam satu tahun terakhir, bersedia menjadi responden.

Pengumpulan data dengan wawancara dan observasi. Penilaian rumah tinggal mengikuti Pedoman Teknis Penilaian Rumah Sehat
(Depkes RI, 2007). Keseluruhan data dianalisis secara univariat dengan frekuensi dan proporsi, serta bivariate dengan chi square (alpha $=0,05$ ). Data disajikan dalam bentuk tabel.

\section{HASIL}

\section{Gambaran Variabel Penelitian}

Hasil penelitian mendapatkan proporsi kejadian ISPA di Desa Kotagajah sebesar $43,4 \%$. Sebanyak $65,4 \%$ rumah masuk dalam kategori padat. Berdasarkan kualitas fisik udara dalam rumah, proporsi rumah dengan suhu udara tidak memenuhi syarat lebih besar $(58,0 \%)$ dibandingkan yang memenuhi syarat $(42,0 \%)$. Demikian pula pada pengukuran kelembaban, sebanyak 54,6\% rumah tinggal memiliki kelembaban yang tidak memenuhi syarat kesehatan.

Pada penilaian konstruksi rumah, Mayoritas rumah tingga telah memiliki ventilasi yang memenuhi syarat kesehatan $(74,1 \%)$, memiliki kondisi lantai memenuhi syarat $(81,0 \%)$, kondisi lantai memenuhi syarat $(81,0 \%)$, dan memiliki lubang asap dapur (70,7\%). Distribusi variabel penelitian pada Tabel 1 .

Tabel 1. Gambaran Variabel penelitian

\begin{tabular}{lcc}
\hline \multicolumn{1}{c}{ Variabel Penelitian } & $\mathrm{n}$ & $\%$ \\
\hline Kejadian ISPA & 89 & 43,4 \\
$\quad$ ISPA & 116 & 56,6 \\
$\quad$ Tidak ISPA & & \\
Kepadatan Hunian Kamar & 134 & 65,4 \\
$\quad$ Padat huni & 71 & 34,6 \\
$\quad$ Tidak padat huni & & \\
Suhu & 119 & 58,0 \\
$\quad$ Tidak Memenuhi Syarat & 86 & 42,0 \\
$\quad$ Memenuhi Syarat & & \\
Kelembaban & 112 & 54,6 \\
$\quad$ Tidak Memenuhi Syarat & 93 & 45,4 \\
$\quad$ Memenuhi Syarat & & \\
$\quad \begin{array}{l}\text { Ventilasi Alamiah } \\
\quad \text { Tidak memenuhi syarat }\end{array}$ & 63 & 30,7 \\
$\quad$ Memenuhi syarat & 152 & 74,1 \\
Kondisi Lantai & & \\
$\quad$ Tidak Memenuhi Syarat & 39 & 19,0 \\
$\quad$ Memenuhi Syarat & 166 & 81,0 \\
Kondisi Dinding & & \\
$\quad$ Tidak Memenuhi Syarat & 39 & 19,0 \\
$\quad$ Memenuhi Syarat & 166 & 81,0 \\
Lubang asap dapur & & \\
$\quad$ Tidak Ada & 60 & 29,3 \\
$\quad$ Ada & 145 & 70,7 \\
\hline
\end{tabular}

\section{Hubungan Variabel Penelitian dan ISPA}

Analsisi hubungan menggunakan uji Chisquare pada alpha $=0,05$. Hasil penelitian 
mendapatkan bahwa sebagian besar responden yang tinggal di rumah dengan kategori padat $(64,9 \%)$, tidak menderita ISPA. Sedangkan yang tinggal di rumah dengan kategori tidak padat, sebanyak 59,2\% menderita ISPA. Hasil analisis statistik menunjukkan hubungan yang bermakna pada kedua variabel ( $p$-value $<0,05$ ).

Lebih dari separuh $(52,9 \%)$ responden yang tinggal di rumah dengan suhu tidak memenuhi syarat menderita ISPA. Pada kelompok yang tinggal di rumah dengan suhu memenuhi syarat, mayoritas tidak menderita ISPA $(69,8 \%)$. Hasil analisis statistik menunjukkan hubungan yang bermakna antara suhu ruangan dengan kejadian ISPA (p-value $<0,05$ ).

Tidak berbeda dengan kelembaban udara dalam rumah. Lebih dari separuh $(52,7 \%)$ responden yang tinggal di rumah dengan kelembaban tidak memenuhi syarat menderita ISPA. Pada kelompok yang tinggal di rumah dengan kelembaban memenuhi syarat, mayoritas tidak menderita ISPA $(67,7 \%)$. Hasil analisis statistik menunjukkan hubungan yang bermakna antara kelembaban ruangan dengan kejadian ISPA (p-value $<0,05)$.

Lebih dari separuh $(52,4 \%)$ responden yang tinggal di rumah dengan ventilasi tidak memenuhi syarat menderita ISPA. Pada kelompok yang tinggal di rumah dengan ventilasi memenuhi syarat, mayoritas tidak menderita ISPA $(63,2 \%)$. Hasil analisis statistik menunjukkan hubungan yang bermakna antara ventilasi dengan kejadian ISPA ( $p$-value $<0,05$ ).

Mayoritas responden yang tinggal di rumah dengan kondisi lantai tidak memenuhi syarat menderita ISPA (79,5\%). Sedangkan yang tinggal di rumah dengan kondisi lantai memenuhi syarat, mayoritas tidak menderita ISPA $(65,1 \%)$. Hasil analisis statistik menunjukkan hubungan yang bermakna antara kondisi lantai dengan kejadian ISPA (pvalue $<0,05)$.

Sebagian besar responden yang tinggal di rumah dengan kondisi dinding tidak memenuhi syarat menderita ISPA (84,6\%). Sedangkan yang tinggal di rumah dengan kondisi dinding memenuhi syarat, mayoritas tidak menderita ISPA $(66,3 \%)$. Hasil analisis statistik menunjukkan hubungan yang bermakna antara kondisi dinding dengan kejadian ISPA (pvalue $<0,05)$.

Pada variabel lubang asap dapur, proporsi responden yang tinggal di rumah dengan lubang asap dapur memenuhi syarat maupun tidak memenuhi syarat lebih tinggi tidak menderita ISPA, yaitu sebesar $56,7 \%$ dan $56,6 \%$. Hasil analisis statistik tidak menunjukkan hubungan yang bermakna antara lubang asap dapur dengan kejadian ISPA ( $p$-value>0,05).

Tabel 2 Hubungan Kondisi Rumah Dengan Kejadian ISPA

\begin{tabular}{|c|c|c|c|c|c|}
\hline \multirow{2}{*}{ Kondisi Rumah } & \multicolumn{2}{|c|}{ ISPA } & \multicolumn{2}{|c|}{ Tidak ISPA } & \multirow{2}{*}{$\mathrm{p}$-value } \\
\hline & $\mathrm{n}$ & $\%$ & $\mathrm{n}$ & $\%$ & \\
\hline \multicolumn{6}{|l|}{ Kepadatan Hunian Kamar } \\
\hline Padat huni & 47 & 35,1 & 87 & 64,9 & \multirow[t]{2}{*}{0,001} \\
\hline Tidak padat huni & 42 & 59,2 & 29 & 40,8 & \\
\hline \multicolumn{6}{|l|}{ Suhu } \\
\hline Tidak Memenuhi Syarat & 63 & 52,9 & 56 & 47,1 & \multirow{2}{*}{0,002} \\
\hline Memenuhi Syarat & 26 & 30,2 & 60 & 69,8 & \\
\hline \multicolumn{6}{|l|}{ Kelembaban } \\
\hline Tidak Memenuhi Syarat & 59 & 52,7 & 53 & 47,3 & \multirow[t]{2}{*}{0,001} \\
\hline Memenuhi Syarat & 30 & 32,3 & 63 & 67,7 & \\
\hline \multicolumn{6}{|l|}{ Ventilasi Alamiah } \\
\hline Tidak memenuhi syarat & 33 & 52,4 & 30 & 47,6 & \multirow[t]{2}{*}{0,05} \\
\hline Memenuhi syarat & 56 & 36,8 & 96 & 63,2 & \\
\hline \multicolumn{6}{|l|}{ Kondisi Lantai } \\
\hline Tidak Memenuhi Syarat & 31 & 79,5 & 8 & 20,5 & \multirow[t]{2}{*}{0,0001} \\
\hline Memenuhi Syarat & 58 & 34,9 & 108 & 65,1 & \\
\hline \multicolumn{6}{|l|}{ Kondisi Dinding } \\
\hline Tidak Memenuhi Syarat & 33 & 84,6 & 6 & 15,4 & \multirow[t]{2}{*}{0,0001} \\
\hline Memenuhi Syarat & 56 & 33,7 & 110 & 66,3 & \\
\hline \multicolumn{6}{|l|}{ Lubang asap dapur } \\
\hline Tidak Ada & 26 & 43,3 & 34 & 56,7 & \multirow[t]{2}{*}{0,888} \\
\hline Ada & 63 & 43,4 & 82 & 56,6 & \\
\hline
\end{tabular}




\section{PEMBAHASAN}

\section{Kepadatan Hunian Kamar}

Hasil analisis data menunjukkan hubungan yang signifikan antara kepadatan hunian kamar dengan kejadian ISPA. Hal ini disebabkan tidak seimbangnya jumlah penghuni dengan luas kamar tidur responden. Hasil penelitian ini sesuai dengan penelitian Aristi dkk (2015) yang menyatakan adanya hubungan yang bermakna antara kepadatan hunian kamar dengan kejadian ISPA di Wilayah Kerja Puskesmas Medang Kampai Kelurahan Teluk Makmur Kecamatan Medang Kampai.

Tingginya kepadatan hunian dipengaruhi masih rendahnya kemampuan masyarakat untuk memiliki rumah sendiri. Sehingga banyak keluarga yang tinggal dalam satu rumah, baik bersama orang tua, saudara, atau mertua. Menurut Depkes RI (1999) luas ruang tidur minimal $8 \mathrm{~m}^{2}$ dan tidak dianjurkan digunakan lebih dari 2 orang. Pengaturan kepadatan hunian kamar sebagai salah satu pencegahan terjadinya penularan penyakit infeksi pernafasan, salah satunya ISPA.

Kepadatan hunian juga dapat mempengaruhi kualitas udara dalam ruangan. Tingginya tingkat kepadatan hunian akan meningkatkan suhu ruangan dan kadar $\mathrm{CO}_{2}$ dalam ruangan. (Kemenkes RI, 2013). Untuk menanggulangi masalah ini, maka perlu memperhatikan tingkat kepadatan hunian rumah dan hunian kamar. Sistem ventilasi yang baik menjadi variabel yang juga harus diperhatikan dalam perbaikan kualitas udara dalam rumah.

\section{Suhu Udara}

Hasil analisis data menunjukkan bahwa ada hubungan antara suhu dengan kejadian ISPA. Hasil pengukuran suhu udara dalam rumah berkisar antara $33^{\circ} \mathrm{C}-37^{\circ} \mathrm{C}$. Menurut Soemirat (2010), temperatur udara akan menentukan kualitas udara dan daya tahan hidup mikroorganisme di dalamnya. Mikroorganisme akan melakukan interaksi dengan lingkungan untuk mempertahankan hidup. Jenis Stafilococcus bakteri penyebab penyakit ISPA tumbuh dengan baik pada suhu $37^{\circ} \mathrm{C}$. Batas suhu untuk pertumbuhannya adalah $15^{\circ} \mathrm{C}$ dan $40^{\circ} \mathrm{C}$, sedangkan suhu pertumbuhan optimum ialah $35^{\circ} \mathrm{C}$.

Penelitian ini sesuai dengan penelitian yang telah dilakukan oleh Supit dkk (2016) yang menyatakan bahwa ada hubungan antara suhu dengan kejadian penyakit ISPA pada balita di Desa Talawaan Kecamatan Wori Kabupaten
Minahasa utara. Beberapa upaya yang dapat dilakukan untuk pengendalian antara lain dengan perbaikan ventilasi, meningkatkan masuknya sinar matahari ke dalam rumah. Kondisi langit-langit, lantai dan dinding yang kedap air juga menjadi faktor yang mempengaruhi suhu udara dalam ruangan.

\section{Kelembaban Udara}

Hasil penelitian menunjukkan hubungan yang bermakna antara kelembaban dengan kejadian ISPA. Hasil pengukuran menunjukkan sebanyak 56,4\% rumah responden memiliki kelembaban ruangan yang tidak memenuhi syarat kesehatan. Kelembaban merupakan presentasi jumlah air di udara atau banyaknya uap air yang berada di udara (BMKG). Menurut Depkes (1999), kelembaban udara dalam rumah dikategorikan memenuhi syarat jika 40\%-60\%, dan dikatakan tidak memenuhi syarat jika $<40 \%$ atau $>60 \%$.

Kelembaban yang tidak memenuhi syarat dapat menyebabkan membrane mukosa hidung menjadi kering sehingga kurang efektif dalam menghadang masuknya mikroorganisme. Selain itu, kelembaban yang tinggi juga dapat meningkatkan jumlah mikroorganisme dalam ruangan. Menurut Soemirat (2010), kelembaban udara yang tinggi akan meningkatkan daya tahan dan jumlah mikroorganisme di udara. Penelitian ini sesuai dengan Lingga dkk (2015) yang menyatakan hubungan signifikansi antara kelembaban rumah dengan kejadian ISPA pada balita di kelurahan Gundaling I Kecamatan Berastagi Kabupaten Karo.

Upaya yang dapat dilakukan untuk menaggulangi masalah kelembaban antara lain dengan meningkatkan suhu udara dengan meningkatkan jumlah sinar matahari yang masuk ke rumah, misalnya dengan membuka jendela dan memasang genteng kaca. Upaya lain adalah dengan melakukan perbaikan konstruksi rumah, yaitu langit-langit, lantai dan dinding yang kedap air.

\section{Ventilasi Alamiah}

Hasil analisis data menunjukkan hubungan bermakna antara ventilasi alamiah dengan kejadian ISPA. Luas ventilasi merupakan salah satu faktor lingkungan yang dapat menjadi faktor risiko penyakit ISPA. Ventilasi berfungsi untuk menjamin kualitas dan kecukupan udara yang keluar dan masuk ke dalam ruangan. Sealin itu, ventilasi berkaitan erat dengan kelembaban udara dalam rumah. Berdasarkan 
Depkes RI (1999), luas ventilasi permanen rumah sehat minimal $10 \%$ dari luas lantai. Demikian pula menurut Notoadmodjo (2007), luas ventilasi yang memenuhi syarat kesehatan adalah $10 \%$ dari luas lantai rumah,

Penelitian ini sesuai dengan penelitian dengan Marlina dkk (2014) yang menyatakan hubungan bermakna antara ventilasi alamiah dengan kejadian ISPA pada anak balita di Puskesmas Panyabunganjae Kabupaten Mandailing Natal. Penelitian lain oleh Safrizal (2017), juga menyatakan hubungan yang bermakna antara ventilasi alamiah dengan kejadian ISPA pada anak balita di Blang Muko. Upaya pengendalian yang adap dilakukan adalah meningkatkan luas ventilasi hingga minimal $10 \%$ luas lantai, serta membuka jendela pada siang hari.

\section{Kondisi Lantai}

Hasil penelitian menunjukkan hubungan bermakna antara jenis lantai rumah dengan kejadian ISPA. Walaupun sebagian besar lantai rumah telah memenuhi syarat kesehatan (81,0\%), namun pada kelompok rumah yang tidak memenuhi syarat masih menggunakan lantai tanah. Penelitian ini sesuai dengan Bee (2014) yang menyatakan hubungan bermakna antara lantai rumah dengan kejadian ISPA pada balita di Wilayah Kerja Puskesmas Salibubu Kabupaten Kepulauan Talaud (Pangemanan, 2016)

Lantai tidak kedap air akan meningkatkan kelembaban udara dalam rumah akibat naiknya uap air dari dalam tanah. Kelembaban yang tinggi akan meningkatkan daya tahan dan jumlah mikroorganisme di udara. Menurut Depkes RI (1999), rumah sehat harus memiliki lantai yang kedap air, dapat terbuat dari marmer, ubin, keramik, atau semen sudah dihaluskan. Upaya yang dapat dilakukan untuk pengendalian antara lain dengan melakukan perbaikan konstruksi lantai, selain memperhatikan faktor pencahayaan dan ventilasi.

\section{Kondisi Dinding}

Mayoritas dinding rumah tinggal telah memenuhi syarat kesehatan $(81,0 \%)$. Pada kelompok yang belum memenuhi syarat, dinsing rumah terbuat dari kayu atau bambu. Hasil analisis statistik menunjukkan hubungan yang signifikan antara jenis dinding rumah dengan kejadian ISPA. Hal ini dikarenakan sebagian responden masih memiliki jenis dinding yang terbuat dari papan/kayu. Hasil penelitian ini sesuai dengan Safrizal (2016) yang menyatakan hubungan bermakna antara dinding rumah dengan kejadian ISPA pada baita di Gampong Blang Muko Kecamatan Kuala Kabupaten Nagan Raya.

Dinding merupakan suatu struktur yang membatasi suatu bangunan dan menyokong struktur lainnya, serta melindungi ruang dari alam terbuka. Dinding yang tidak rapat dan tidak kedap air dapat menyebabkan kelembaban ruangan menjadi tinggi, serta masuknya debu ke dalam rumah. Rumah yang konstruksi dindingnya tidak baik akan sulit untuk menjaga kebersihannya, karena permukaan dinding yang tidak permanen, tidak halus dan tidak rata menyebabkan debu dan kotoran lain yang menempel sulit dibersihkan. Dinding yang tidak rapat menyebabkan masuknya kotoran dari luar seperti debu, asap atau kotoran lainnya. Dinding rumah dari bambu ataupun bahan lain yang memungkinkan kesempatan untuk masuknya debu dan polutan lainnya. Upaya pengendalian yang dapat dilakukan antara lain dengan perbaikan konstruksi dinding sehingga menjadi rapat dan kedap air.

\section{Lubang Asap Dapur}

Lubang asap dapur berfungsi sebagai tempat keluarnya asap pembakaran dari dapur. Hasil penelitian mendapatkan $70,7 \%$ rumah telah memeilki lubang asap dapur yang memenuhi syarat kesehatan. Hasil analisis statistik tidak menunjukkan hubungan yang bermakna antara lubang asap dapur dengan kejadian ISPA (pvalue $>0,05$ ). Lubang asap dapur penting agar asap pembakaran dapat langsung keluar dari dalam rumah. Rumah yang tidak memiliki lubang asap dapur menyebabkan gas $\mathrm{CO}_{2}$ dan partikulat masuk ke dalam rumah, sehingga meningkatkan risiko ISPA.

Penelitian ini sesuai dengan Noviyanti (2012) yang menyatakan tidak ada hubungan signifikan antara lubang asap dengan kejadian penyakit ISPA pada balita di Sekitar Wilayah Tempat Pembuangan Akhir Sampah (TPAS) Tamangapa Kota Makasar.

\section{KESIMPULAN}

Hasil penelitian mendapatkan proporsi kejadian ISPA di Desa Kotagajah sebesar 43,4\%. Berdasarkan hasil analisis data, ditemukan tujuh variabel yang berhubungan signifikan dengan kejadian ISPA, yaitu kepadatan hunian kamar, suhu udara, 
kelembaban udara, ventilasi, kondisi lantai, dan kondisi dinding rumah. Terdapat satu variabel yang tidak menunjukkan hubungan, yaitu lubang asap dapur. Diperlukan upaya perbaikan kualitas udara dalam rumah dengan melakukan perbaikan konstruksi rumah dan perilaku, misalnya membuka jendela pada siang hari.

\section{DAFTAR PUSTAKA}

Aristi, Indra, Reni; Marsaulina, Irnawati; Ashar,Taufik, 2015. Hubungan Pengetahuan Dan Sikap Kepada Keluarga Tentang Rumah Sehat Terhadap Infeksi Saluran Pernafasan Akut Di Wilayah Kerja Puskesmas Teluk Makmur Medang Kampai Kelurahan Teluk Makmur Kecamatan Medang Kota Dumai Tahun 2014,kampus USU Medan.

Bee, Winarni; Alkali, Rahayu; Sinolungan, Jehosua, 2014. Hubungan Antara Kondisi Lingkungan Fisik Rumah Dengan Kejadian Infeksi Saluran Pernafasan Akut (ISPA) Pada Anak Baita Di Wilayah Kerja Puskesmas Salibubu, Jurnal Fakultas Kesehatan Masyarakat dan Fakultas Kedokteran Sam Ratulangi, Manado.

Depkes RI, 1999, Keputusan Menteri Kesehatan RI. Menteri Kesehatan Republik Indonesia No. 829/Menkes/SK/VII/1999 tentang persyaratan kesehatan perumahan.

Depkes RI, 2007, Pedoman Teknis Penilaian Rumah Sehat, Jakarta: Ditjen P2PLh

Kemenkes RI. (2013). Profil Kesehatan Indonesia. Jakarta.

Kemenkes RI, 2018. Laporan Nasioanl Riskesdas. Badan Penelitian dan Pengembangan Kemenkes RI, Jakarta.

Lingga Raja Nindangi., Nurmaini., Santi, Devi Nuraini., 2015. Hubungan Karakteristik Rumah Dengan Kejadian ISPA pada Balita dalam keluarga Perokok di Kelurahan Gundaling I Kecamatan Berastagi Kabupaten Karo Tahun 2014. https://media.neliti.com/media/publications $/ 14534$
Marlina, Andriani, 2014. Hubungan pengetahuan dan sikap ibu terhadap kejadian ISPA pada balita di Wilayah keja Puskesmas Tigo Baleh Bukit Tinggi. Jurnal STIKES Yarsi Sumatera Barat, Bukit Tinggi.

Notoatmodjo, Soekidjo, 2010. Metodologi penelitian kesehatan, Jakarta 243 halaman.

Noviyanti, Vovi, 2012. Faktor-Faktor Yang Mempengaruhi Kejadian Penyakit Ispa Pada Balita Di Sekitar Wilayah Tempat Pembuangan Akhir Sampah (TPAS) Tamangapa Kota Makassar Tahun 2012. Fakultas Ilmu Kesehatan Universitas Islam Negeri Alauddin Makassar.

Pangemanan, Junitje; Sumampouw, Oksfriani; Alkili, Rahayu, 2016. Hubungan Antara Kondisi Fisik Rumah Dengan Kejadian ISPA Pada Anak Balita Di Wilayah Puskesmas Melonguane Kabupaten Kepulauan Talaud.

Puskesmas Rawat Inap Kotagajah, 2016. Profil puskesmas Rawat Inap Kotagajah Tahun 2016

Safrizal, SA, 2016. Hubungan Ventilasi, Lantai, Dinding, Dan Atap Dengan Kejadian ISPA Pada Balita Di Blang Muko, Kota Aceh

Soemirat, Juli, 2010. Epidemiologi lingkungan,Bandung. Gajah Mada University Pers : 199 halaman.

Supit, Frits, Ade; Joseph, B.S, Woodford; Kaunang, P.J,Wulan, 2016. Hubungan Antara Lingkungan Fisik Rumah Dengan Kejadian Penyakit Infeksi Saluran Pernafasan Akut Pada Balita Di Desa Talawaan Atas Dan Desa Kima Bajo Kecamatan Wori Kabupaten Minahsa Utara, Kota Manado.

World Health Organization, 2007, Pencegahan dan Pengendalian Infeksi Saluran Pernapasan Akut (ISPA) yang Cenderung Menjadi Epidemi dan Pandemi di Fasilitas Pelayanan Kesehatan, Jenewa: World Health Organization (WHO) 